Bangladesh Med Res Counc Bull 2009; 35: 21-25

DOI: $10.3329 /$ bmrcb.v35i1.2533

\title{
Corn extracts lower tissue arsenic level in rat
}

\author{
Noor Jahan Alam Chowdhury, Mir Misbahuddin and Md. Sayedur Rahman \\ Division of Arsenic Research, Department of Pharmacology, Faculty of Basic Medical Sciences, \\ Bangabnadhu Sheikh Mujib Medical University, Shahbag, Dhaka, Bangladesh.
}

\begin{abstract}
This study was carried out to see whether corn extracts could reduce the accumulation of arsenic in different tissues of rat. Exposure to arsenic $(700 \mu \mathrm{g} / \mathrm{rat} / \mathrm{day})$ orally for 15 days led to significant accumulation of arsenic and significant reduction in the concentration of reduced glutathione (GSH) in different tissues. While water, salt, ethanol and alkali extracts of corn were co-administered at a dose of $0.5 \mathrm{~mL} / \mathrm{rat} /$ day orally by stomach tube during last 8 days, arsenic concentration decreased significantly in all tissues and reduced glutathione (GSH) concentration increased significantly in tissues except heart and skin. Among the extracts, water extract produced maximum reduction of arsenic $(69.07 \%$ in liver, $64.98 \%$ in kidney, $63.47 \%$ in lung, $57.55 \%$ in heart and $69.30 \%$ in skin) and elevation of reduced glutathione level in all tissues $(17.03 \%$ in liver, $46.73 \%$ in lung, $32.67 \%$ in heart and $55.38 \%$ in skin) except kidney, in which maximum elevation of reduced glutathione was attained by ethanol extract $(23.14 \%)$. This study suggests that corn extracts might protect rats from accumulation of arsenic in different tissues and oxidative stress, which is reflected by the increasing reduced glutathione concentration in those tissues.
\end{abstract}

\section{Introduction}

The contamination of ground water by arsenic is a major health problem in Bangladesh. About 57 millions people in Bangladesh are exposed to arsenic $>10 \mu \mathrm{g} / \mathrm{L}$ through arsenic contaminated tube well water and about 35 millions to arsenic $>50 \mu \mathrm{g} / \mathrm{L}^{1}$. Until now, about 38,000 cases of arsenicosis patients have been identified, though unfortunately still there is no specific treatment. The supportive treatments for arsenicosis are retinol, $\beta$-carotene ${ }^{2}$, ascorbic acid $^{3}, \alpha$-tocophe$\mathrm{rol}^{4}$, zinc ${ }^{5}$, selenium ${ }^{6}$ and spirulina ${ }^{7}$. All of these agents are antioxidants and require long duration (4-12 months) of treatment. This leads to poor compliance and make the treatment expensive as well. Furthermore, the recurrence rate is high. Therefore, there is need to discover a drug effective with short duration of treatment, lesser incidence of recurrence and comparatively cheaper.

Corn has been an important nutritional resource for the thousands of years because of its high protein and carbohydrate content. Several studies involving whole grain intakes have shown a consistent protective role in reducing the risk of colorectal cancer, breast cancer, coronary heart disease, diabetes and reduced total mortality ${ }^{8-10}$. The present study was conducted to look at the efficacy of different extracts of corn in protecting rats from accumulation of arsenic and consequent oxidative stress in different organs.

\section{Materials and Methods}

Chemicals: Arsenic trioxide and silver diethyldithiocarbamate were procured from E. Merck (Germany). Reduced glutathione (GSH) and 5,5 dithiobis-2-nitrobenzoic acid (DTNB) were procured from Sigma Chemical Company (USA). All other chemicals used in the study were of analytical grade.

Procedure for obtaining different extracts of corn: Corn was collected from the market and crushed by blender machine. Then $50 \mathrm{~g}$ of crushed corn was soaked in $60 \mathrm{~mL}$ of deionized water for $30 \mathrm{~min}$. After $30 \mathrm{~min}$ the supernatant was filtered out and the procedure was repeated twice. All water extracts were kept in a labeled container. The residue was subsequently treated with $500 \mathrm{mM} \mathrm{NaCl}, 50 \%$ ethanol and $50 \mathrm{mM}$ $\mathrm{NaOH}$ solution in similar manner. The extracts were then kept in separate labeled container. Finally water $(80 \mathrm{~mL})$, salt $(115 \mathrm{~mL})$, ethanol 
$(120 \mathrm{~mL})$ and alkali $(120 \mathrm{~mL})$ extracts were obtained.

Experimental design: The study was carried out on Long Evans Norwegian strains of adult healthy male rats. The rats were weighing between 160-180 $\mathrm{g}$ and 3-4 months aged. Throughout the experiment, the rats were kept in standard stainless cages. They were allowed living at room temperature in a clean, well ventilated rodent room where a 12/12 hours light/dark cycle was maintained. They were fed on standard pellets of rat food and allowed to drink ad libitum.

Rats were randomly divided into 6 groups of 6 rats each. Group I served as control and rats in Groups II-VI received $700 \mu \mathrm{g}$ of arsenic everyday by stomach tube for 15 days $^{11}$. Of these rats, Groups III to VI received $0.5 \mathrm{ml}$ of corn extracts (water, salt, ethanol and alkali) from day 8 to day 15 by stomach tube respectively.

The rats of all groups were sacrificed under chloroform anesthesia on day 16. Blood samples were collected by cutting throat with sharp blade and were treated with and without heparin. The liver, kidneys, lungs and heart were dissected out and the skin was isolated. These organs were packed in separate polyethylene packets with accurately labeled and preserved at $-20^{\circ} \mathrm{C}$ until the period of analysis.

Preparation of erythrocytes: Heparinized blood samples were centrifuged at 4,000 rpm for $5 \mathrm{~min}$ and the plasma and buffy coat was discarded by removing from the top. The packed RBCs were washed three times with five volumes buffered saline $(0.9 \%$ saline in $10 \mathrm{mM}$ phosphate buffer, $\mathrm{pH}$ 7.4) by centrifugation at $4,000 \mathrm{rpm}$ for 5 min. The packed cells were then suspended in an equal volume of the distilled deionized water to lyse RBCs.

Preparation of serum: Blood samples without heparin were centrifuged at 4,000 rpm for $5 \mathrm{~min}$ and the serum was collected by pasture pipette into labeled test tube.

Preparation of tissue homogenate: Tissue was clean properly in a petri dish containing Tyrode's solution at $0-4^{\circ} \mathrm{C}$ (resting in ice birth) and carefully weighed of $500 \mathrm{mg}$ in case of liver, kidneys, lungs, skin and $300 \mathrm{mg}$ of heart.
Clean tissue was then chopped into small pieces and homogenated properly by a hand tissue homogenizer with $4 \mathrm{~mL}$ Tyrode's solution and keeping the homogenizer in the ice bath.

Estimation of tissue arsenic level: Liver, kidneys, lungs, heart and skin were wet digested and concentration of arsenic in the digested samples was measured by using SDDC (silver diethyldithio carbamate) method at $525 \mathrm{~nm}$. The detection level of arsenic was $8 \mu \mathrm{g} / \mathrm{L}$.

Estimation of GSH: GSH level was assayed by Ellman's method ${ }^{12}$. In brief, $1 \mathrm{~mL}$ of tissues homogenate, serum and erythrocytes was added to $1 \mathrm{~mL}$ of $5 \%$ trichloroacetic acid and the mixture was vortexes and centrifuged at 4,000 $\mathrm{rmp}$ for $5 \mathrm{~min}$. Then $250 \mu \mathrm{L}$ of supernatant was added to $2 \mathrm{~mL} \mathrm{Na}_{2} \mathrm{HPO}_{4}(4.25 \%)$ and $250 \mu \mathrm{L}$ of DTNB $(0.04 \%)$. The mixture was allowed to stand for approximately $10 \mathrm{~min}$, and forming a yellow substance. The absorbance was measured at $412 \mathrm{~nm}$ using spectrophotometer.

Analysis of corn proteins by SDS-PAGE electrophoresis: Four extracts of corn and protein standard (BSA) were dissolved in sample loading buffer in a 2:1 ratio and heated the mixture to $100^{\circ} \mathrm{C}$ for $5 \mathrm{~min}$. Proteins were separated using SDS-PAGE system consisting of an upper stacking gel of $1 \mathrm{~mL} \quad 30 \% \quad 29: 1$ acrylamide/bisacrylamide stock solution in 0.75 $\mathrm{mL} 1.5 \mathrm{M}$ gel buffer ( $\mathrm{pH}$ 6.8), and a linear gradient resolving gel consisting of $4.32 \mathrm{~mL}$ $30 \% \quad 29: 1$ acrylamide/bisacrylamide stock solution in $4 \mathrm{~mL} 1.5 \mathrm{M}$ gel buffer ( $\mathrm{pH} 8.8$ ). Polymerization of acrylamide was induced by addition of N,N,N',N'tetramethylethylenediamine and ammonium persulfate. Proteins were fixed and stained in a solution of water: methanol: glacial acetic acid (200: 250: $50 \mathrm{~mL}$ ) containing $1 \mathrm{~g}$ Coomassie blue (Sigma, Cheme). Gels were destained in a solution of $250 \mathrm{~mL}$ methanol and $50 \mathrm{~mL}$ glacial acetic acid.

Statistical analysis: Statistical analysis was done by Statistical Package for Social Science (SPSS), version 12. The quantitative variables were expressed as mean \pm SD. ANOVA (multiple comparisons) was done for statistical analysis. Post hoc analyses of differences were done by Bonferroni ' $t$ ' test. Pearson correlationcoefficient was done to see the relationship between arsenic and glutathione concentration. 


\section{Results}

Table I shows arsenic concentration in liver, kidneys, lungs, heart and skin of arsenic exposed rat treated with different extracts of corn. On exposure to arsenic, arsenic concentration was significantly increased and concomitant administration with different extracts of corn showed significant depletion of arsenic concentration in these tissues. The reduction was observed highest in case of water extract followed by ethanol extract. Marked reduction of arsenic concentration was observed in skin $(69.30 \%)$ followed by liver, kidneys, lungs and heart $(69.07 \%, 64.98 \%, 63.47 \%$, and
$57.55 \%$ respectively) when treated with water extract.

Exposure to arsenic led to a significant depletion of GSH concentration in liver, kidneys, lungs, heart, skin, serum and erythrocytes (Table II). Treatment with different extracts of corn showed significant increase of GSH concentration in liver, kidneys, lungs, serum and erythrocytes. The increase was highest by water extract followed by ethanol extract except in kidneys but no significant increase in heart and skin. Other two extracts, i.e., salt and alkali, brought no significant changes in the above mentioned tissues.

Table I: Effect of different extracts of corn on arsenic concentration in different organs of rat

\begin{tabular}{|c|c|c|c|c|c|}
\hline Group & Liver & Kidneys & Lungs & Heart & Skin \\
\hline Control & $2.07 \pm 0.68$ & $2.02 \pm 0.80$ & $1.58 \pm 0.54$ & $3.03 \pm 0.96$ & $1.41 \pm 0.50$ \\
\hline Arsenic & $18.98 \pm 1.98^{\mathrm{a}}$ & $20.79 \pm 1.29^{\mathrm{a}}$ & $14.70 \pm 1.15^{\mathrm{a}}$ & $20.26 \pm 2.34^{\mathrm{a}}$ & $13.16 \pm 1.20^{\mathrm{a}}$ \\
\hline Arsenic + water extract & $5.87 \pm 0.91 *$ & $7.28 \pm 0.54^{*}$ & $5.37 \pm 1.29 *$ & $8.60 \pm 1.87^{*}$ & $4.04 \pm 0.71 *$ \\
\hline Arsenic + salt extract & $8.60 \pm 1.48^{*}$ & $9.21 \pm 1.10^{*}$ & $7.93 \pm 1.05 *$ & $12.42 \pm 1.92 *$ & $6.23 \pm 1.09 *$ \\
\hline Arsenic + ethanol extract & $6.97 \pm 1.52 *$ & $7.55 \pm 1.06^{*}$ & $6.05 \pm 1.31 *$ & $8.76 \pm 1.69^{*}$ & $4.95 \pm 1.25^{*}$ \\
\hline Arsenic + alkali extract & $12.76 \pm 2.10^{*}$ & $11.81 \pm 0.92 *$ & $9.93 \pm 0.80^{*}$ & $16.04 \pm 2.16^{*}$ & $8.70 \pm 1.10^{*}$ \\
\hline
\end{tabular}

Values are mean $\pm \mathrm{SD} ; \mathrm{n}=6 ;{ }^{\mathrm{a}} \mathrm{p}<0.001$ compared to control group as analyzed by unpaired $\mathrm{t}$-test; ${ }^{*} \mathrm{p}<0.001$ compared to arsenic exposed group as analyzed by ANOVA (multiple comparisons by Bonferroni ' $t$ ' test)

Table II: Effect of different extracts of corn on reduced glutathione concentration in different organs, serum and erythrocytes of rat

\begin{tabular}{lccccccc}
\hline Group & Liver & Kidneys & Lungs & Heart & Skin & Serum & Erythrocytes \\
\hline Control & $10.24 \pm 0.61$ & $6.45 \pm 0.64$ & $2.15 \pm 0.29$ & $5.63 \pm 0.92$ & $1.58 \pm 0.32$ & $0.20 \pm 0.02$ & $11.83 \pm 1.36$ \\
Arsenic & $7.81 \pm 0.27^{\mathrm{a}}$ & $4.58 \pm 0.40^{\mathrm{a}}$ & $1.07 \pm 0.14^{\mathrm{a}}$ & $3.52 \pm 2.08^{\mathrm{a}}$ & $0.65 \pm 0.15^{\mathrm{a}}$ & $0.11 \pm 0.03^{\mathrm{a}}$ & $7.16 \pm 1.43^{\mathrm{a}}$ \\
Arsenic + water & $9.14 \pm 0.66^{*}$ & $5.64 \pm 0.54^{*}$ & $1.57 \pm 0.14^{*}$ & $4.67 \pm 1.37$ & $1.01 \pm 0.27$ & $0.16 \pm 0.01^{*}$ & $10.22 \pm 1.03^{*}$ \\
$\begin{array}{l}\text { extract } \\
\text { Arsenic + salt }\end{array}$ & $8.21 \pm 0.52$ & $4.87 \pm 0.50$ & $1.25 \pm 0.15$ & $3.83 \pm 1.48$ & $0.84 \pm 0.21$ & $0.14 \pm 0.02$ & $8.44 \pm 1.13$ \\
$\begin{array}{l}\text { extract } \\
\text { Arsenic + ethanol }\end{array}$ & $8.96 \pm 0.51^{*}$ & $5.69 \pm 0.55^{*}$ & $1.49 \pm 0.13^{*}$ & $4.61 \pm 1.63$ & $0.93 \pm 0.31$ & $0.15 \pm 0.02^{*}$ & $9.69 \pm 1.51^{*}$ \\
$\begin{array}{l}\text { extract } \\
\text { Arsenic + alkali }\end{array}$ & $8.08 \pm 0.62$ & $4.72 \pm 0.43$ & $1.13 \pm 0.17$ & $3.56 \pm 1.61$ & $0.76 \pm 0.15$ & $0.12 \pm 0.03$ & $7.48 \pm 1.18$ \\
extract & & & & & & & \\
\hline
\end{tabular}

Values are mean $\pm \mathrm{SD} ; \mathrm{n}=6 ;{ }^{\mathrm{a}} \mathrm{p}<0.001$ compared to control group as analyzed by unpaired $\mathrm{t}$-test; ${ }^{*} \mathrm{p}<0.001$ compared to arsenic exposed group as analyzed by ANOVA (multiple comparisons by Bonferroni ' $t$ ' test)

Electrophoretic analysis of corn proteins by differential solubility is illustrated in Figure 1. Several protein bands in corn proteins, e.g.albumin (water soluble), globulin (salt soluble) and prolamin (ethanol soluble) were separated by SDS-PAGE, however glutelin (alkali soluble) could not be identified clearly.

\section{Discussion}

The present study shows that different extracts of corn (water, salt, ethanol and alkali extract) are effective in removal of arsenic and increase the concentration of reduced glutathione in different organs of rat. Among the extracts, water extract was most effective and about $60-70 \%$ arsenic was removed from all the tissues by this extract. The beneficial role of water extract might be due to presence of proteins and amino acids ${ }^{15}$. Corn protein products and citric acid derivatives exhibited promising metal-chelating properties ${ }^{16}$. Accordingly, the presence of these two amino acids and protein in water extract of corn might be contributing in removal of arsenic from different tissues. In another study, four different corn proteins were identified by SDS-PAGE electrophoresis by differential solubility. The researchers found several albumin and globulin polypeptides over a large range of molecular 
mass, but globulin appeared to be composed mainly of subunits with a molecular mass ranging from 25 to $50 \mathrm{kDa}$. Prolamin consisted of two major subunits of 22 and $24 \mathrm{kDa}$ and glutelin consisted of three main polypeptides of 31,50 and $55 \mathrm{kDa}^{17}$. In that study, several pro-

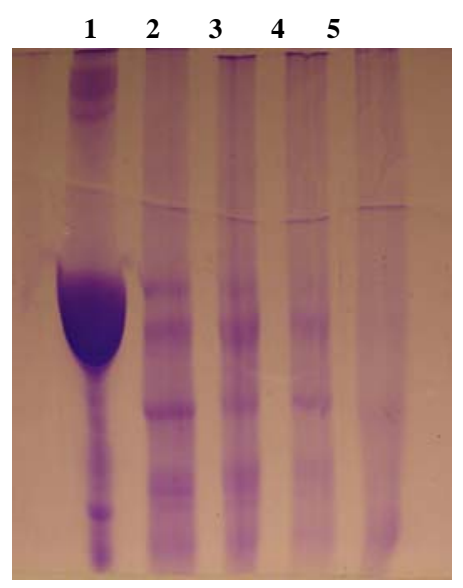

--- $66.2 \mathrm{kDa}$

Figure 1: SDS-PAGE analysis of corn proteins (Lane 1: bovine serum albumin (BSA) $66.2 \mathrm{kDa}$ (protein standard); Lane 2: water extract of corn; Lane 3: $0.5 \mathrm{M}$ sodium chloride extract of corn; Lane 4: 50\% ethanol extract of corn; Lane 5: $0.05 \mathrm{M} \mathrm{NaOH}$ extract of corn

ein bands were identified in corn proteins like albumin (water soluble), globulin (salt soluble) and prolamin (ethanol soluble) by SDS-PAGE but not in glutelin (alkali soluble). The present study also showed that ethanol extract of corn is effective in removal of arsenic from tissues which might be due to the presence of highest amount of natural antioxidants like phenolic, flavonoid, ferulic acid content and total antioxidant activity in ethanol extract of $\operatorname{corn}^{18}$.

GSH also plays an important role in the detoxification via facilitating removal of arsenic from the cellular sites and stimulating excretion of methylated arsenic ${ }^{19}$, which is responsible for arsenic induced cytotoxicity. Arsenic intoxication resulted in significant depletion of GSH in the blood, liver and brain, kidney and heart ${ }^{20-21}$. The present study also showed that there was significant decrease in the reduced glutathione concentration in blood, liver, kidney, lungs, heart and skin of rats after arsenic exposure. This was known earlier that the recovery of the depleted GSH significantly enhances in presence of vitamins such as vitamin $\mathrm{A}^{22}$, ascorbate and $\alpha$-tocopherol ${ }^{4}$. As the corn contains $\alpha$-tocopherol, ascorbate and vitamin A in the form of $\beta$-carotene, possibly these substances helped to recover the depleted GSH in different tissues and blood of rat.

Finally, it can be concluded from this study that corn might be effective in the removal of arsenic from different tissues of rat. However, more studies are required to examine the effect on laboratory animal models and patients of chronic arsenic poisoning.

\section{References}

1. Garelick H, Agnieszka Dybowska A, ValsamiJones E, Priestl ND. Remediation technologies for arsenic contaminated drinking waters. J Soils Sediments 2005; 5: 182-90.

2. Chung JS, Haque R, Guha Mazumder DN, Moore LE, Ghosh N, Samanta S, Mitra S, Hira-Smith MM, von Ehrenstein O, Basu A, Liaw J, Smith AH. Blood concentration of methionine, selenium, beta-carotene, and other micronutrients in a case-control study of arsenic-induced skin lesions in West Bengal, India. Environ Res. 2006; 101: 230-37.

3. Saha B. Effect of ascorbic acid on reduced glutathione level in arsenic-loaded isolated liver tissues of rat. Bangladesh J Pharmacol. 2006; 1: 68-71.

4. Ramanathan K, Shila S, Kumaran S, Panneerselvam C. Protective role of ascorbic acid and $\alpha$-tocopherol on arsenic-induced microsomal dysfunctions. Hum Exp Toxicol. 2003; 22: 12936.

5. Kamaluddin M, Misbahuddin M. Zinc supplement reduces tissue arsenic concentration in rats. Bang Med Res Counc Bull. 2006; 32: 8791.

6. Momin A, Ali SK, Haque MM. Randomized placebo-controlled trial to evaluate the effectiveness of selenium in the treatment of arsenocosis patients. In: Applied research on arsenic in Bangladesh. Misbahuddin M (ed). Dhaka, World Health Organization (Bangladesh), Director General of Health services, Govt. of Bangladesh, 2007, pp 17-30.

7. Misbahuddin $\mathrm{M}$, Islam AZMM, Khandker S, Mahmud IA, Islam N, Anjumanara. Efficacy of spirulina extract plus zinc in patients of chronic poisoning: A randomized placebo-controlled study. Clin Toxicol. 2006; 44: 135-41.

8. Jacobs DR Jr, Slavin J, Marquart L. Whole grain intake and cancer: A review of the literature. Nutr Cancer. 1995; 24: 221-9.

9. Jacobs DR Jr, Meyer KA, Kushi LH, Folsom AR. Whole-grain intake may reduce the risk of ischemic heart disease death in postmenopausal 
women: the Iowa Women's Health Study. Am J Clin Nutr. 1998; 68: 248-57.

10. Jacobs DR, Meyer HE, Solvoll K. Reduced mortality among whole grain bread eaters in men and women in the Norweign county study. Eur J Clin Nutr. 2001; 55: 137-43.

11. Umar BU. Effect of hexane extract of spinach in the removal of arsenic from rat. Bangladesh $\mathrm{J}$ Pharmacol. 2007; 2: 27-34.

12. Ellman L. Tissue sulfhydryl groups. Arch Biochem Biophys. 1959; 82: 70-77.

13. Ligget RW, Koffler H. Corn steep liquor in microbiology. Bacteriol Rev. 1948; 12: 297-311.

14. Keller, Heckman LLP. Assessment plan for corn steep liquor in accordance with the USEPA high production volume chemical challenge program. The Corn Refiners Association, 2006, pp 1-10.

15. Sessa DJ, Wing RE. Metal chelation of corn protein products/ citric acid derivatives generated via reactive extrusion. Ind Crop Prod. 1999; 10: 55-63.
16. Romagnolo D, Polan CE, Barbeau WE. Electrophoretic analysis of ruminal degradability of corn proteins. J Dairy Sci 1994; 77: 1093-99.

17. Adom KK, Liu RH. Antioxidant activity of grains. J Agric Food Chem. 2002; 50: 6182-7.

18. Vahter M. Mechanism of arsenic biotransformation. Toxicology 2002; 181: 21117.

19. Flora SJS. Arsenic induced oxidative stress and reversibility following combined administration of $\mathrm{N}$-acetylecysteine and meso-2, 3 dimercaptosuccinic acid in rats. Clin Exp Pharmacol Physiol. 1999; 26: 865-69.

20. Ramos O, Carrizales L, Yanez L, Meija J, Batres L, Ortiz, Diaz-Barriga F. Arsenic increased lipid peroxidation in rat tissues by a mechanism independent of glutathione levels. Environ Health Perspect. 1995; 103 (Suppl 1): 85-88.

21. Gopalkrishnan A, Rao MV. Amelioration by vitamin A upon chronic arsenic induced metabolic and neurotoxic effects. J Health Sci. 2006; 52: 568-77. 